\title{
EFFECT OF SPACING AND SEEDLING PER HILL ON THE PERFORMANCE OF AUS RICE var. BRRI dhan48
}

\author{
T. A. Ninad 1 , M. M. Bahadur' 2 , M. A. Hasan'2, M. M. Alam³ and M. S. Rana ${ }^{1}$ \\ ${ }^{1}$ M. S. Student, Dept. of Crop Physiology and Ecology, Hajee Mohammad Danesh Sci. and Tech. University, Dinajpur \\ 2Professor, Dept. of Crop Physiology and Ecology, Hajee Mohammad Danesh Sci. and Tech. University, Dinajpur \\ ${ }^{3}$ Lecturer, Dept. of Agronomy, Shahid Akber Ali Science and Technology College, Thakurgaon.
}

(Received: 20 April 2017, Accepted: 7 December 2017)

Key words: Spacing, No. of seedling, yield, var. BRRI dhan48, Aus rice

\begin{abstract}
An experiment was conducted at the research field and laboratory in the Department of Crop Physiology and Ecology, Hajee Mohammad Danesh Science and Technology University, Dinajpur, during the period of April to August, 2016 to study the effect of spacing and number of seedlings hill ${ }^{-1}$ on the yield of $A u s$ rice var. BRRI dhan 48 . Four spacing's viz. $20 \mathrm{~cm} \times 10 \mathrm{~cm}, 20 \mathrm{~cm} \times 15 \mathrm{~cm}, 20 \mathrm{~cm} \times 20 \mathrm{~cm}$ and $20 \mathrm{~cm} \times 25 \mathrm{~cm}$ and three number of seedlings hill ${ }^{-1}$ viz. 1,2 and 4 were included in the study. Results indicated that the highest number of total tillers hill ${ }^{-1}$ (22.86), number of effective tillers hill $^{-1}$ (21.24), number of grains panicle ${ }^{-1}(128.79)$ and 1000-grain weight $(23.30 \mathrm{~g})$ were found with $20 \mathrm{~cm} \times 25 \mathrm{~cm}$ spacing. The highest plant height $(104.27 \mathrm{~cm})$, number of leaves plant ${ }^{-1}$ (35.80), grain yield (3.06 tha $\left.{ }^{-1}\right)$, straw yield (3.37 tha $\left.{ }^{-1}\right)$ and harvest index were obtained from $20 \mathrm{~cm} \times 10 \mathrm{~cm}$ spacing. The highest grain yield of $2.98 \mathrm{t}$ ha ${ }^{-1}$ was obtained from 4 seedlings hill-1 ${ }^{-1}$ while the lowest $2.47 \mathrm{t} \mathrm{ha}^{-1}$ from 1 seedlings hill $^{-1}$. The highest grain yield of 3.40 tha $^{-1}$ was obtained from $20 \mathrm{~cm} \times 10 \mathrm{~cm}$ spacing with 4 seedlings hill- ${ }^{-1}$ while the lowest grain yield of 2.21 tha $^{-1}$ from the wider spacing. Results of the present study revealed that $20 \mathrm{~cm} \times 10 \mathrm{~cm}^{2}$ spacing with 4 seedlings hill-1 combination was found to be the best for obtaining maximum grain yield of Aus rice var. BRRI dhan48.
\end{abstract}

\section{Introduction}

Rice is the most extensively cultivated staple food crop for the people of Bangladesh. It plays a vital role in Bangladesh agriculture as it covers 74 per cent of total cultivable area (AIS, 2001). The total production under rice cultivation in Bangladesh about 19.1 million tons from Boro, 13.02 million tons from Aman and 2.6 million tons from Aus rice in 2014-15 (BBS, 2015). Rice is grown in three distinct season's viz. aus, aman and boro among which aus rice covers only $12.27 \%$ of the rice growing area. The average yield of rice in aus is only 1.45 (BBS, 2001). So, among these three seasons, rice yield is the lowest in Aus season as compared to the other growing seasons and therefore, efforts should be made to increase the yield of Aus rice. Optimum plant density ensures proper growth of the aerial and underground parts of the plant through efficient utilization of solar radiation, nutrients, land as well as air spaces and water (Miah et al., 1990). Regardless of plant spacing within and among rows, plant density must be such that the crop develops a canopy able to intercept more than 95\% of the incoming solar radiation during reproductive growth. Baloch et al. (2002) reported that appropriate plant density of a cultivar is necessary for obtaining higher yield and quality of rice. 
Ninad et al.

Number of seedlings hill-1 is an important factor for successful rice production which affects plant population unit ${ }^{-1}$ area, availability of sunlight and nutrients, photosynthesis and respiration, which ultimately influence the yield of crop (Chowdhury et al., 1993). Excess number of seedlings hill ${ }^{-1}$ may produce higher number of tillers hill-1 ${ }^{-1}$ resulting in mutual shading and lodging and thus favouring the production of higher grain and straw yield, while less number of seedlings hill ${ }^{-1}$ may cause reduction of total number of panicles in per unit area which may be associated with poor yield. Therefore, an experiment was conducted to find out the effect of spacing and number of seedlings hill- ${ }^{-1}$ on the yield of Aus rice var. BRRI dhan 48 .

\section{Materials and Methods}

The experiment was conducted at the research farm and laboratory of Crop Physiology and Ecology Department, Hajee Mohammad Danesh Science and Technology University (HSTU), Dinajpur during April to August, 2016 to study the effect of spacing and number of seedlings hill $^{-1}$ on the yield of Aus rice var. BRRI dhan48. The experimental field was a medium high land belonging to the non-calcareous dark gray floodplain soil under the Agro-Ecological Zone (AEZ-1) of Old Himalayan Piedmont Plain (FAO, 2005). Treatments include four spacing's viz. $20 \mathrm{~cm} \times 10 \mathrm{~cm}, 20 \mathrm{~cm} \times 15 \mathrm{~cm}, 20 \mathrm{~cm} \times 20 \mathrm{~cm}$ and $20 \mathrm{~cm} \times 25 \mathrm{~cm}$ and three numbers of seedlings hill ${ }^{-1}$ viz. 1,2 and 4 were. The experiment was carried out in a randomized complete block design with three replications. The unit plot size was $3.0 \mathrm{~m} \times 2.0 \mathrm{~m}$. BRRI dhan48 is a high yielding variety of aus rice developed by BRRI was used as planting material. The experimental land was prepared through ploughing and cross ploughing and fertilized with urea, triple super phosphate (TSP) muriate of potash (MOP), gypsum and zinc sulphate at the rate of $180,100,60,60$ and $10 \mathrm{~kg} \mathrm{ha}^{-1}$, respectively. Twenty five days old seedlings were transplanted on $5^{\text {th }}$ May, 2016 with $20 \mathrm{~cm}$ spacing between lines and 10, 15, 20 and $25 \mathrm{~cm}$ spacing between hills in respective treatment Intercultural operations were done for maintaining the normal growth and development of the crop. The crop was harvested at full maturity and five hills were randomly selected from each unit plot for recording of necessary data. The collected data was analyzed by using the "Analysis of variance" (ANOVA) technique with the help of a computer package (MSTAT-C) program (Gomez and Gomez, 1984).

\section{Results and Discussion}

Plant height $(\mathrm{cm})$ : The effect of row spacing and number of seedling hill-1 ${ }^{-1}$ on plant height at different days after transplanting (DAT) was statistically significant (Table. 1). Results showed that plant height increased with decreasing row spacing. The tallest plant was recorded at $S_{1}$ $(20 \mathrm{~cm} \times 10 \mathrm{~cm})$ spacing while shortest plant was recorded at $S_{4}(20 \mathrm{~cm} \times 25 \mathrm{~cm})$ spacing. The taller plant in densely populated plants might have resulted due to competition for sunlight than those of wider spacing as reported by Abbas et al. (1994) and Akita et al. (1992). Result showed that at $35,55,75$ DAT and at harvest $\mathrm{N}_{3}$ (4 seedlings hill-1) showed the longest plant while $\mathrm{N}_{1}$ (1 seedling hill-1) showed shortest plant. The result was similar with the findings of Shrirame et al. (2000) and Shah et al. (1991). Results indicated that the longest plant was found in $20 \mathrm{~cm} \times 10 \mathrm{~cm}$ spacing with 4 seedlings hill-1 $\left(\mathrm{S}_{1} \mathrm{~N}_{3}\right)$.

Number of leaves hill-1. Significant variations were observed in number of leaves hill-1 ${ }^{-1}$ at 55 and 75 DAT as influenced due to row spacing (Table 1). Results showed that $S_{1}$ treatment was 
evident for the highest number of leaves hill ${ }^{-1}$ and the lowest in $S_{4}$. In case of number of seedling hill-1 4 seedling hill ${ }^{-1}$ showed highest number of leaves per hill while lowest number of leaves hill-1 ${ }^{-1}$ from 1 seedling hill ${ }^{-1}$ which was supported by Shrirame et al. (2000). Interaction effect indicated that the highest number of leaves hill-1 was found $S_{1} N_{3}$ and the lowest number in $\mathrm{S}_{4} \mathrm{~N}_{1}$ at 55 and 75 DAT.

Number of total tillers hill-1 ${ }^{-1}$ The highest number of total tillers hill-1 was recorded at $S_{4}(20 \mathrm{~cm}$ $\times 25 \mathrm{~cm})$ and the lowest at $S_{1}(20 \mathrm{~cm} \times 10 \mathrm{~cm})$ spacing. Reduction in total tillers hill-1 in closer spacing might be due to increased number of plants per unit area. This increased number of plants per unit area exerted competition among plants for nutrients and light that caused a reduction in tiller number. Similar results were also reported by Baloch et al. (2002) in rice. Results showed that (4 seedling hill ${ }^{-1}$ showed the highest number of total tillers hill ${ }^{-1}$ (23.47). The results are in conformity with Karmakar et al. (2002), Shrirame et al. (2000) and BINA (1987). In case of interaction the highest number of total tillers hill ${ }^{-1}$ was found in $\mathrm{S}_{4} \mathrm{~N}_{3}$ and the lowest one in $\mathrm{S}_{1} \mathrm{~N}_{1}$.

Number of effective tillers hill ${ }^{-1}$ : The effect of row spacing, seedling number hill ${ }^{-1}$ and the interaction was statistically significant (Table 2). The highest number of effective tillers hill ${ }^{-1}$ was recorded at $20 \mathrm{~cm} \times 25 \mathrm{~cm}$ spacing and the lowest $20 \mathrm{~cm} \times 10 \mathrm{~cm}$ spacing Increase in effective tillers hill ${ }^{-1}$ in wider spacing might be due to increased number of plants per unit area. Similar results were also reported by Baloch et al. (2002) in rice. The highest number of effective tillers hill-1 ${ }^{-1}$ was found from 4 seedlings hill-1 ${ }^{-1}$ and the lowest number with 1 seedlings hill $^{-1}$ which was supported by Islam (1980).

Number of non-effective tillers hill-1 ${ }^{-1}$ Row spacing, seedling number hill ${ }^{-1}$ and the interaction had significant influence on transplant aus rice (Table 2). The highest number of non-effective tillers hill-1 (6.69) was observed in $S_{1}$ and the lowest one (5.22) in closer spacing of $S_{4}$ Reduction in the number of non-effective tiller in widely populated area might be due to plant can able to produce effective tiller at later growth stages which was in agreement with those of Baloch et al. (2002). It was observed that the highest number of non-effective tillers hill-1 ${ }^{-1}$ (7.17) was found in $\mathrm{S}_{1} \mathrm{~N}_{1}$ and the lowest one (4.00) in S4N3.

Length of panicle $(\mathrm{cm})$ : The longest panicle length $(23.35 \mathrm{~cm})$ was produced by $20 \mathrm{~cm} \times 25$ $\mathrm{cm}$ spacing and the shortest one $(20.97 \mathrm{~cm})$ by $20 \mathrm{~cm} \times 10 \mathrm{~cm}$. similar results was observed by Lious (1987) who stated that closer spacing decreased panicle length. The longest panicle length $(24.40 \mathrm{~cm})$ was produced by 4 seedlings hill ${ }^{-1}$ and the shortest one $(20.02 \mathrm{~cm})$ by 1 seedlings hill ${ }^{-1}$.

Number of grains panicle ${ }^{-1}$ : The highest number of grains panicle $e^{-1}(128.79)$ was observed in $20 \mathrm{~cm} \times 25 \mathrm{~cm}$ spacing while lowest number of grains panicle-1 (104.17) in $20 \mathrm{~cm} \times 10 \mathrm{~cm}$ spacing. Reduction in the number of grains panicle ${ }^{-1}$ under closer spacing might be due to increased number of plants per unit area. This increased number of plants per unit area exerted competition among plants for nutrients and light that might have caused lower crop growth rate with consequently a reduction in the number of filled grains panicle $e^{-1}$ which was supported by Sarker et al. (2002) and Ghosh et al. (1988). It was found that more seedling with higher no. of grains while less no. of seedling produced lowest (111.30) number of grains panicle $e^{-1}$. 
Ninad et al.

Number of sterile spikelet's panicle-1: Result revealed that the number of sterile spikelets panicle $e^{-1}$ decreased with increasing row spacing. The highest number of sterile spikelets panicle $e^{-1}(27.06)$ was found in 1 seedling hill ${ }^{-1}$. The highest number of sterile spikelets panicle $e^{-1}$ (30.50) was obtained from $20 \mathrm{~cm} \times 10 \mathrm{~cm}$ with 1 seedlings hill-1 and the lowest one (20.00) from $20 \mathrm{~cm} \times 25 \mathrm{~cm}$ with 4 seedlings hill ${ }^{-1}$.

Thousand-grain weight $(\mathrm{g})$ : The highest 1000 -grain weight $(23.30 \mathrm{~g})$ was recorded from $20 \mathrm{~cm}$ $\times 25 \mathrm{~cm}$ spacing and the lowest one $(22.51 \mathrm{~g})$ from $20 \mathrm{~cm} \times 10 \mathrm{~cm}$ spacing. 1000-grain weight decreased with increasing plant density in rice which was obtained by Baloach et al. (2002) and Yan et al. (2007). Result revealed that 4 seedling hill-1) showed highest 1000 grains weight (24.20g) while 1 seedling hill-1 ${ }^{-1}$ showed the lowest 1000 grains weight $(21.87 \mathrm{~g})$. Similar findings were observed by Wen and Yang (1991). In interaction, the highest 1000- grain weight $(24.60 \mathrm{~g})$ was found in $\mathrm{S}_{4} \mathrm{~N}_{3}$ and lowest one $(21.57 \mathrm{~g})$ in $\mathrm{S}_{1} \mathrm{~N}_{1}$.

Grain yield (tha $a^{-1}$ ): Grain yield was significantly influenced by spacing, number of seedlings hill-1 and the interaction (Fig. 1, $2 \& 3$ ). The highest $\left(3.06\right.$ tha $\left.^{-1}\right)$ grain yield was recorded in $20 \mathrm{~cm}$ $\times 10 \mathrm{~cm}$ spacing and the lowest grain yield $\left(2.47 \mathrm{tha}^{-1}\right)$ in wider row spacing of $20 \mathrm{~cm} \times 25$ $\mathrm{cm}$. The highest grain yield was recorded in closer spacing might be due to highest number of plants per unit area which was supported by Neelam and Nisha (2000) Kang et al. (2001) and Baloach et al.(2002). Result revealed that more seedling showed the highest grain yield (2.98 tha $\left.^{-1}\right)$ where the lowest grain yield $\left(2.47\right.$ tha $\left.^{-1}\right)$ with 1 seedling hill-1 ${ }^{-1}$ Similar results were also found by Islam et al. (2002) and Obulamma et al. (2002). The interaction between $20 \mathrm{~cm} \times 10$ $\mathrm{cm}$ with 4 seedlings hill ${ }^{-1}$ produced the highest grain yield $\left(3.40\right.$ tha $\left.^{-1}\right)$ and $20 \mathrm{~cm} \times 25 \mathrm{~cm}$ with 1 seedlings hill ${ }^{-1}$ produced the lowest grain yield $\left(2.21\right.$ tha $\left.^{-1}\right)$.

Straw yield (tha-1): Straw yield was significantly influenced by spacing, number of seedlings hill ${ }^{-1}$ and their interaction (Fig. 1, $2 \&$ 3). The highest straw yield was recorded in $20 \mathrm{~cm} \times 10 \mathrm{~cm}$ spacing (3.37 tha ${ }^{-1}$ ) and the lowest in $2025 \mathrm{~cm}$ spacing (3.07 tha $\left.{ }^{-1}\right)$. The result is consistent with the findings of Baloach et al. (2002). Result revealed that 4 seedling hill-1 showed the highest straw yield (3.61 tha $\left.{ }^{-1}\right)$, while the lowest straw yield $\left(2.92\right.$ tha $\left.^{-1}\right)$ with 1 seedling hill-1 . The results found by Karmakar et al. (2002) and Shrirame et al. (2000) were similar with the findings. The interaction between $20 \mathrm{~cm} \times 10 \mathrm{~cm}$ with 4 seedlings hill ${ }^{-1}$ produced the highest straw yield $\left(3.75\right.$ tha $\left.^{-1}\right)$ and $20 \mathrm{~cm} \times 25 \mathrm{~cm}$ with 1 seedling hill-1 produced the lowest straw yield $\left(2.78\right.$ tha $\left.^{-1}\right)$.

Harvest index (\%): The highest harvest index was observed in wider row spacing of $20 \mathrm{~cm} \times$ $10 \mathrm{~cm}(47.63 \%)$ and the lowest one (44.52\%) from the spacing of $20 \mathrm{~cm} \times 25 \mathrm{~cm}$. Result revealed that 4 seedlings hill-1) showed the highest harvest index $(47.12 \%)$ where the lowest (45.69\%) with 1 seedling hill-1 ${ }^{-1}$ which was also achieved by Karmakar et al. (2002), Shrirame et al. (2000) and BINA (1993). The interaction between $20 \mathrm{~cm} \times 10 \mathrm{~cm}$ with 4 seedlings hill $^{-1}$ produced the highest harvest index $(47.55 \%)$ and $20 \mathrm{~cm} \quad 25 \mathrm{~cm}$ with 1 seedlings hill-1 produced the lowest harvest index (44.34\%). 
Effect of Spacing and Seedling Per Hill on the Performance

Table 1. Effect of spacing and number of seedling hill-1 on plant height, number of leaves hill-1 and number of total tillers hill-1 of $A u s$ rice at different days after transplanting (DAT)

\begin{tabular}{|c|c|c|c|c|c|c|c|c|c|c|c|}
\hline \multirow{2}{*}{$\begin{array}{c}\text { Treatment } \\
\text { Spacing }\end{array}$} & \multicolumn{4}{|c|}{ Plant height $(\mathrm{cm})$} & \multicolumn{3}{|c|}{ Leaves hill ${ }^{-1}$ (no.) } & \multicolumn{4}{|c|}{ Total tillers hill-1(no.) } \\
\hline & 35 DAT & 55 DAT & 75 DAT & $\begin{array}{c}\text { At } \\
\text { harvest }\end{array}$ & 35 DAT & 55 DAT & 75 DAT & 35 DAT & 55 DAT & 75 DAT & $\begin{array}{c}\text { At } \\
\text { harvest }\end{array}$ \\
\hline $\mathrm{S}_{1}$ & $60.00 a$ & $79.22 \mathrm{a}$ & $99.99 a$ & $104.27 a$ & 21.03 & $29.11 a$ & $35.80 a$ & $7.28 \mathrm{~d}$ & $10.28 \mathrm{~d}$ & $15.81 d$ & $22.86 a$ \\
\hline $\mathrm{S}_{2}$ & $59.11 \mathrm{ab}$ & 78.67ab & $99.66 a$ & $103.72 \mathrm{a}$ & 20.23 & $28.33 a$ & $34.94 \mathrm{ab}$ & $8.44 c$ & $11.28 \mathrm{c}$ & $17.39 c$ & $21.96 b$ \\
\hline $\mathrm{S}_{3}$ & $58.00 \mathrm{bc}$ & 78.67ab & $96.56 b$ & $100.90 b$ & 19.11 & $28.72 a$ & $33.93 b c$ & $8.89 b$ & $12.17 b$ & $18.11 \mathrm{~b}$ & $21.14 \mathrm{c}$ \\
\hline $\mathrm{S}_{4}$ & $57.67 \mathrm{c}$ & $77.67 b$ & $96.36 b$ & $100.75 b$ & 20.01 & $26.42 b$ & $32.82 \mathrm{c}$ & $10.17 \mathrm{a}$ & $13.00 \mathrm{a}$ & $19.44 a$ & $20.34 d$ \\
\hline $\begin{array}{c}\text { Level of } \\
\text { significance }\end{array}$ & $* *$ & $*$ & $* *$ & $* *$ & NS & $* *$ & $* *$ & $* *$ & $* *$ & $* *$ & *** \\
\hline \multicolumn{12}{|l|}{ Seedling hill-1 } \\
\hline $\mathrm{N}_{1}$ & $57.17 \mathrm{~b}$ & $76.25 c$ & $94.58 \mathrm{c}$ & $99.22 b$ & $14.35 c$ & $29.11 \mathrm{c}$ & $30.91 \mathrm{c}$ & $6.12 c$ & $9.83 c$ & $15.23 c$ & $19.85 c$ \\
\hline $\mathrm{N}_{2}$ & $57.42 \mathrm{~b}$ & $78.67 b$ & $98.68 b$ & $103.67 a$ & $19.63 b$ & $28.33 b$ & $32.42 \mathrm{~b}$ & $8.96 b$ & $11.79 b$ & $18.13 b$ & $21.41 \mathrm{~b}$ \\
\hline $\mathrm{N}_{3}$ & $61.50 \mathrm{a}$ & $80.75 a$ & $101.16 a$ & $104.35 a$ & $26.32 \mathrm{a}$ & $28.72 \mathrm{a}$ & $39.80 \mathrm{a}$ & $11.00 \mathrm{a}$ & $13.42 \mathrm{a}$ & $19.71 \mathrm{a}$ & $23.47 a$ \\
\hline $\begin{array}{c}\text { Level of } \\
\text { significance }\end{array}$ & $* *$ & $* *$ & $* *$ & $* *$ & $* *$ & $* *$ & $* *$ & $* *$ & $* *$ & $* *$ & $* *$ \\
\hline \multicolumn{12}{|l|}{ Interaction } \\
\hline $\mathrm{S}_{1} \mathrm{~N}_{1}$ & 56.33 & 77.00 & 95.67eg & $101.60 \mathrm{~cd}$ & 15.60 & $21.83 \mathrm{~g}$ & $32.17 \mathrm{ce}$ & $5.33 \mathrm{~h}$ & 8.50 & $14.10 \mathrm{i}$ & $21.20 \mathrm{ef}$ \\
\hline $\mathrm{S}_{1} \mathrm{~N}_{2}$ & 57.67 & 79.33 & $97.33 \mathrm{df}$ & $107.19 b$ & 19.83 & 30.00de & $34.00 \mathrm{c}$ & $8.00 e$ & 10.50 & $16.33 \mathrm{fg}$ & $22.73 c$ \\
\hline $\mathrm{S}_{1} \mathrm{~N}_{3}$ & 63.00 & 82.00 & $107.00 \mathrm{a}$ & $111.56 \mathrm{a}$ & 27.67 & $36.00 \mathrm{a}$ & $41.67 a$ & 8.50de & 11.83 & 17.00ef & $24.65 a$ \\
\hline $\mathrm{S}_{2} \mathrm{~N}_{1}$ & 58.00 & 76.00 & $95.00 \mathrm{fg}$ & $98.92 \mathrm{df}$ & 14.77 & $20.00 \mathrm{~h}$ & $32.17 \mathrm{ce}$ & $6.00 \mathrm{gh}$ & 9.00 & 14.83hi & $20.47 \mathrm{~g}$ \\
\hline $\mathrm{S}_{2} \mathrm{~N}_{2}$ & 59.00 & 77.33 & $98.67 d$ & $100.00 \mathrm{cf}$ & 19.33 & $29.00 \mathrm{ef}$ & 31.00de & $8.83 \mathrm{~d}$ & 11.33 & 17.83de & $21.50 e$ \\
\hline $\mathrm{S}_{2} \mathrm{~N}_{3}$ & 62.00 & 80.33 & $104.30 \mathrm{~b}$ & $106.67 b$ & 26.60 & $35.50 a$ & $41.23 a$ & $10.50 c$ & 13.50 & $19.50 b c$ & $23.90 b$ \\
\hline $\mathrm{S}_{3} \mathrm{~N}_{1}$ & 57.00 & 76.67 & $94.00 \mathrm{~g}$ & $99.04 \mathrm{df}$ & 13.67 & $20.17 \mathrm{~h}$ & 29.80de & $6.17 \mathrm{~g}$ & 10.33 & $15.50 \mathrm{gh}$ & $19.30 \mathrm{~h}$ \\
\hline
\end{tabular}


Ninad et al.

\begin{tabular}{|c|c|c|c|c|c|c|c|c|c|c|c|}
\hline \multirow{2}{*}{$\begin{array}{c}\text { Treatment } \\
\text { Spacing }\end{array}$} & \multicolumn{4}{|c|}{ Plant height (cm) } & \multicolumn{3}{|c|}{ Leaves hill-1 (no.) } & \multicolumn{4}{|c|}{ Total tillers hill-1(no.) } \\
\hline & 35 DAT & $55 \mathrm{DAT}$ & 75 DAT & $\begin{array}{c}\text { At } \\
\text { harvest }\end{array}$ & 35 DAT & 55 DAT & 75 DAT & 35 DAT & 55 DAT & 75 DAT & $\begin{array}{c}\text { At } \\
\text { harvest }\end{array}$ \\
\hline $\mathrm{S}_{3} \mathrm{~N}_{2}$ & 58.33 & 80.00 & $96.00 \mathrm{dg}$ & $98.00 e f$ & 20.00 & $32.00 c$ & $32.33 c d$ & $9.00 \mathrm{~d}$ & 12.33 & $18.67 \mathrm{~cd}$ & $21.13 f$ \\
\hline $\mathrm{S}_{3} \mathrm{~N}_{3}$ & 61.00 & 81.00 & $101.67 \mathrm{c}$ & $105.67 b$ & 23.67 & $34.00 \mathrm{~b}$ & $39.67 a$ & $11.50 \mathrm{~b}$ & 13.83 & $20.17 b$ & $23.00 c$ \\
\hline $\mathrm{S}_{4} \mathrm{~N}_{1}$ & 56.00 & 75.33 & 93.67g & $97.30 f$ & 13.37 & $19.97 \mathrm{~h}$ & $29.50 e$ & $7.00 \mathrm{f}$ & 11.50 & $16.50 \mathrm{fg}$ & $18.42 \mathrm{i}$ \\
\hline $\mathrm{S}_{4} \mathrm{~N}_{2}$ & 56.00 & 78.00 & $96.32 \mathrm{dg}$ & $100.64 \mathrm{ce}$ & 19.33 & $28.00 f$ & $32.33 \mathrm{~cd}$ & $10.00 c$ & 13.00 & $19.67 b c$ & $20.27 \mathrm{~g}$ \\
\hline $\mathrm{S}_{4} \mathrm{~N}_{3}$ & 60.00 & 79.67 & 98.09de & $102.33 c$ & 27.33 & $31.30 \mathrm{~cd}$ & $36.63 b$ & $13.50 \mathrm{a}$ & 14.50 & $22.17 \mathrm{a}$ & $22.34 d$ \\
\hline $\begin{array}{c}\text { Level of } \\
\text { significance }\end{array}$ & NS & NS & *** & $* *$ & NS & $* *$ & $* *$ & $* *$ & NS & *** & $* *$ \\
\hline CV (\%) & 3.21 & 2.40 & 3.50 & 3.64 & 7.45 & 3.10 & 4.17 & 5.00 & 4.31 & 3.33 & 3.89 \\
\hline
\end{tabular}

In a column, values followed by similar letter (s) did not differ significantly by DMRT at $5 \%$ level of significant

Note: NS $=$ Not Significance

$\mathrm{S}_{1}=20 \mathrm{~cm} \times 10 \mathrm{~cm}, \mathrm{~S}_{2}=20 \mathrm{~cm} \times 15 \mathrm{~cm}, \mathrm{~S}_{3}=20 \mathrm{~cm} \times 20 \mathrm{~cm}, \mathrm{~S}_{4}=20 \mathrm{~cm} \times 25 \mathrm{~cm}$

$\mathrm{N}_{1}=1$ seedling, $\mathrm{N}_{2}=2$ seedlings, $\mathrm{N}_{3}=3$ seedling 
Effect of Spacing and Seedling Per Hill on the Performance

Table 2. Effect of spacing and number of seedling hill ${ }^{-1}$ on the yield attributes of Aus rice

\begin{tabular}{|c|c|c|c|c|c|c|c|}
\hline Treatment & $\begin{array}{l}\text { Effective } \\
\text { tillers hill }{ }^{-1} \\
\text { (no.) }\end{array}$ & $\begin{array}{l}\text { Non- } \\
\text { effective } \\
\text { tillers } \\
\text { hill }^{-1} \text { (no.) }\end{array}$ & $\begin{array}{l}\text { Panicle } \\
\text { length } \\
(\mathrm{cm})\end{array}$ & $\begin{array}{l}\text { Grains } \\
\text { panicle }{ }^{-1} \\
\text { (no.) }\end{array}$ & $\begin{array}{c}\text { Sterile } \\
\text { spikelets } \\
\text { panicle }{ }^{-1} \\
\text { (no.) }\end{array}$ & $\begin{array}{c}1000 \text { - } \\
\text { grains } \\
\text { weight } \\
(\mathrm{g})\end{array}$ & $\begin{array}{c}\text { Harvest } \\
\text { index } \\
(\%)\end{array}$ \\
\hline \multicolumn{8}{|l|}{ Spacing } \\
\hline $\mathrm{S}_{1}$ & $18.24 d$ & $6.69 a$ & $20.97 d$ & $104.17 d$ & $28.94 a$ & $22.51 \mathrm{~d}$ & $47.63 a$ \\
\hline $\mathrm{S}_{2}$ & $19.74 \mathrm{c}$ & $6.12 b$ & $21.88 \mathrm{c}$ & $110.72 c$ & $26.55 b$ & $22.80 \mathrm{c}$ & $45.62 b$ \\
\hline $\mathrm{S}_{3}$ & $20.41 b$ & $5.70 \mathrm{bc}$ & $22.63 b$ & $112.83 b$ & $23.62 c$ & $23.08 b$ & $45.05 b c$ \\
\hline $\mathrm{S}_{4}$ & $21.24 \mathrm{a}$ & $5.22 \mathrm{c}$ & $23.35 a$ & $128.79 a$ & $21.69 \mathrm{~d}$ & $23.30 \mathrm{a}$ & $44.52 \mathrm{c}$ \\
\hline Level of significance & $* *$ & $* *$ & $* *$ & $* *$ & $* *$ & $* *$ & $* *$ \\
\hline \multicolumn{8}{|l|}{ Seedling hill-1 } \\
\hline $\mathrm{N}_{1}$ & $17.75 c$ & $6.54 a$ & $20.02 c$ & $111.30 \mathrm{c}$ & $27.06 a$ & $21.87 \mathrm{c}$ & $45.69 c$ \\
\hline $\mathrm{N}_{2}$ & $20.10 b$ & $6.42 \mathrm{a}$ & $22.21 b$ & $113.71 b$ & $25.14 b$ & $22.69 b$ & $46.31 b$ \\
\hline $\mathrm{N}_{3}$ & $21.87 \mathrm{a}$ & $4.84 b$ & $24.40 \mathrm{a}$ & $117.38 \mathrm{a}$ & $23.40 c$ & $24.20 \mathrm{a}$ & $47.12 \mathrm{a}$ \\
\hline Level of significance & $* *$ & $* *$ & $* *$ & $* *$ & $* *$ & $* *$ & $* *$ \\
\hline \multicolumn{8}{|l|}{ Interaction } \\
\hline $\mathrm{S}_{1} \mathrm{~N}_{1}$ & $16.25 \mathrm{~h}$ & $7.17 \mathrm{a}$ & 18.73 & $101.67 \mathrm{~h}$ & $30.50 a$ & $21.57 j$ & 47.15ab \\
\hline $\mathrm{S}_{1} \mathrm{~N}_{2}$ & $18.25 f$ & $7.17 \mathrm{a}$ & 20.75 & $104.00 \mathrm{~g}$ & $29.50 \mathrm{~b}$ & $22.15 \mathrm{~h}$ & $47.20 \mathrm{ab}$ \\
\hline $\mathrm{S}_{1} \mathrm{~N}_{3}$ & $20.22 \mathrm{~d}$ & $5.75 b c$ & 23.42 & $106.83 f$ & $26.83 c$ & $23.80 \mathrm{~d}$ & $47.55 a$ \\
\hline $\mathrm{S}_{2} \mathrm{~N}_{1}$ & $17.25 \mathrm{~g}$ & $6.67 \mathrm{ab}$ & 19.82 & $106.50 f$ & $29.08 b$ & $21.80 \mathrm{i}$ & $45.31 \mathrm{df}$ \\
\hline $\mathrm{S}_{2} \mathrm{~N}_{2}$ & $20.68 d$ & $6.68 \mathrm{ab}$ & 21.83 & $111.33 e$ & $26.20 c$ & $22.50 \mathrm{~g}$ & $46.40 b c$ \\
\hline $\mathrm{S}_{2} \mathrm{~N}_{3}$ & $21.28 \mathrm{c}$ & $5.00 \mathrm{~cd}$ & 24.00 & $114.33 \mathrm{~cd}$ & $24.37 d$ & $24.10 \mathrm{c}$ & $46.17 \mathrm{df}$ \\
\hline $\mathrm{S}_{3} \mathrm{~N}_{1}$ & $18.50 f$ & $6.50 \mathrm{ab}$ & 20.40 & $110.50 e$ & $25.23 \mathrm{~d}$ & $22.03 \mathrm{~h}$ & 44.97ef \\
\hline $\mathrm{S}_{3} \mathrm{~N}_{2}$ & $20.22 \mathrm{~d}$ & $6.00 \mathrm{bc}$ & 22.83 & $113.00 \mathrm{~d}$ & $23.20 e f$ & $22.90 f$ & 45.54ce \\
\hline $\mathrm{S}_{3} \mathrm{~N}_{3}$ & $22.50 \mathrm{~b}$ & 4.60de & 24.67 & $115.00 \mathrm{c}$ & $22.42 \mathrm{fg}$ & $24.30 \mathrm{~b}$ & $46.63 e f$ \\
\hline $\mathrm{S}_{4} \mathrm{~N}_{1}$ & $19.00 e$ & $5.83 \mathrm{bc}$ & 21.13 & $126.53 b$ & $23.42 e$ & $22.09 \mathrm{~h}$ & $44.34 f$ \\
\hline $\mathrm{S}_{4} \mathrm{~N}_{2}$ & $21.25 \mathrm{c}$ & $5.83 \mathrm{bc}$ & 23.42 & $126.50 b$ & $21.67 \mathrm{~g}$ & $23.20 e$ & $46.09 \mathrm{~cd}$ \\
\hline $\mathrm{S}_{4} \mathrm{~N}_{3}$ & $23.47 a$ & $4.00 e$ & 25.50 & 133.33a & $20.00 \mathrm{~h}$ & $24.60 \mathrm{a}$ & $45.80 \mathrm{~cd}$ \\
\hline Level of significance & $* *$ & $* *$ & NS & $* *$ & $* *$ & $* *$ & $* *$ \\
\hline CV (\%) & 7.45 & 12.26 & 5.54 & 6.73 & 11.29 & 3.43 & 4.03 \\
\hline
\end{tabular}

Note: NS= Not Significance

In a column, values followed by similar letter(s) did not differ significantly by DMRT at $\mathrm{P} \leq 5$

$\mathrm{S}_{1}=20 \mathrm{~cm} \times 10 \mathrm{~cm}, \mathrm{~S}_{2}=20 \mathrm{~cm} \times 15 \mathrm{~cm}, \mathrm{~S}_{3}=20 \mathrm{~cm} \times 20 \mathrm{~cm}, \mathrm{~S}_{4}=20 \mathrm{~cm} \times 25 \mathrm{~cm}$

$\mathrm{N}_{1}=1$ seedling, $\mathrm{N}_{2}=2$ seedlings, and $\mathrm{N}_{3}=3$ seedling 


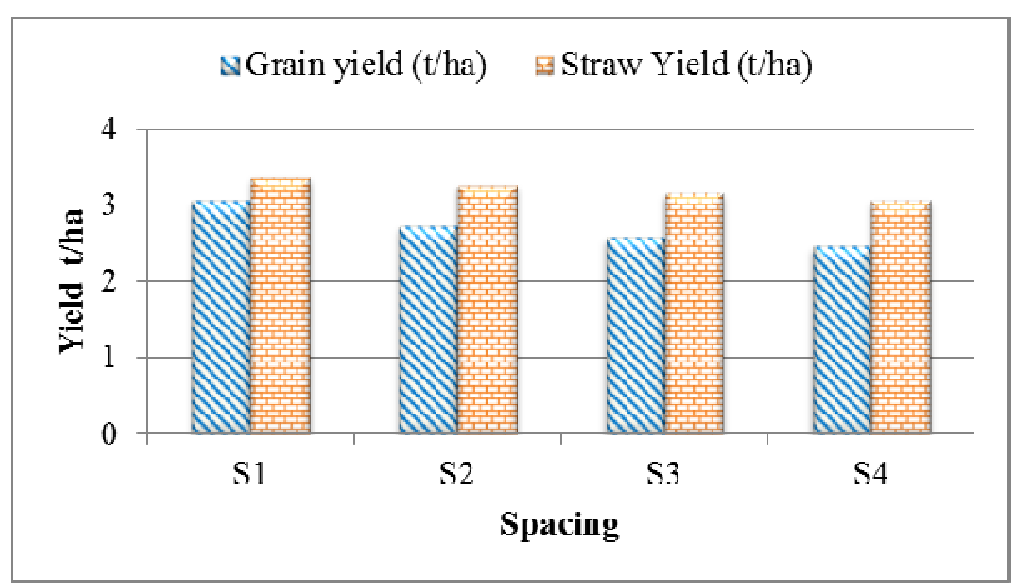

Fig. 1. Effect of spacing on the grain and straw yield $\left(\mathrm{t} \mathrm{ha}^{-1}\right)$ of Aus rice

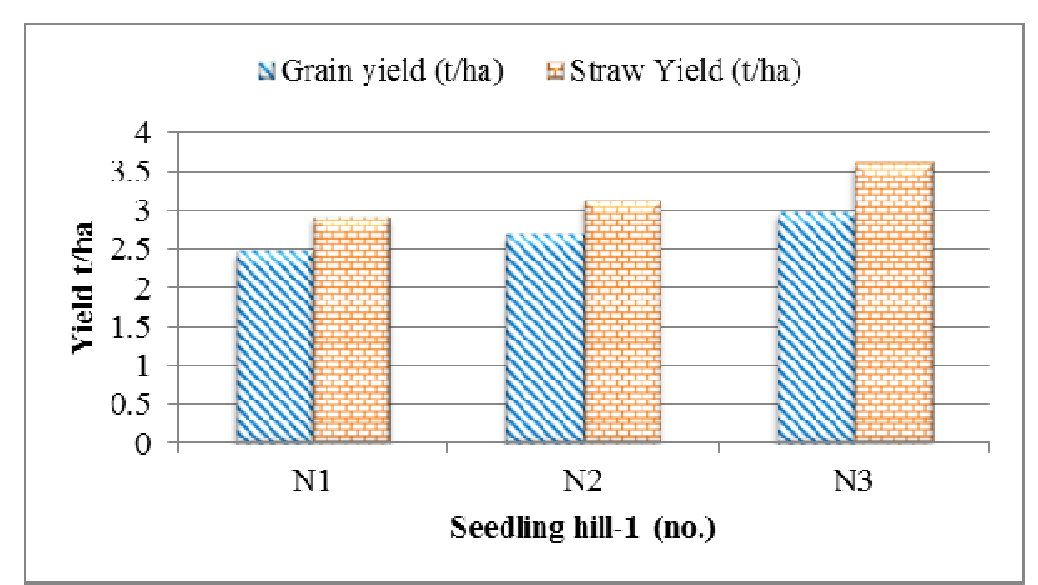

Fig. 2. Effect of number of seedling hill ${ }^{-1}$ on the grain and straw yield (t ha ${ }^{-1}$ ) of Aus rice

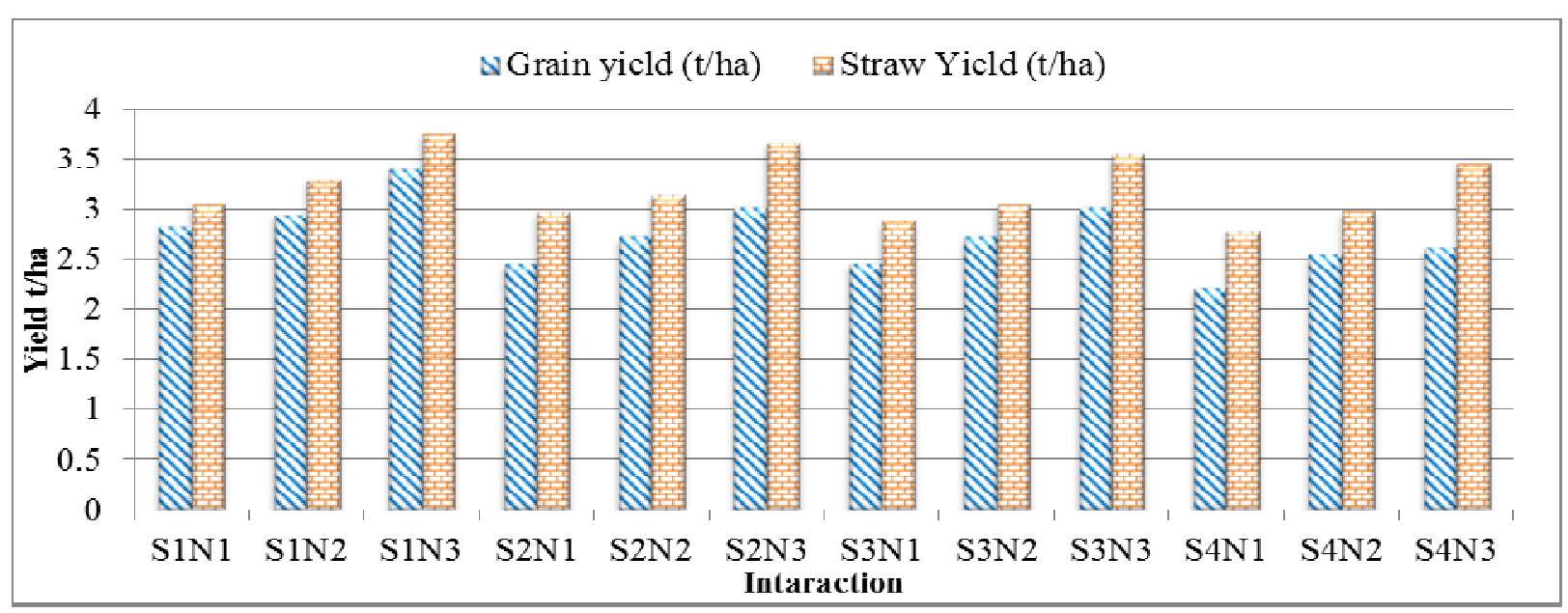

Fig. 3. Effect of interaction between spacing and number of seedling hill ${ }^{-1}$ on the grain and straw yield ( $\left.\mathrm{tha}^{-1}\right)$ of $A u s$ rice 


\section{Conclusion}

Based on the present study it may be concluded that the Aus rice var. BRRI dhan 48 grown under $20 \mathrm{~cm} \times 10 \mathrm{~cm}$ spacing with 4 seedlings hill-1 could obtained optimum grain yield. However, these findings need to be further investigated and evaluated on different agroecological zone before final recommendation to the farmers.

\section{References}

Abbas, M., M. P. Singh, K. B. Nigam and V. S. Kandalkar. 1994. Effect of phosphorus and hill density on yield and yield attributing characters of rice. Indian J. Agron. 39(2): 249-251.

Baloch, A. W., A. M. Soomro, M. A. Javed and M. Ahmed. 2002. Optimum plant density for high yield in rice. Asian J. Plant Sci. 1: 25-27.

BBS (Bangladesh Bureau of Statistics). 2001. Statistical Yearbook of Bangladesh, Bangladesh Bureau of Statistics. Stat. Div. Minis. Plann., Govt. People's Rep. Bangladesh. Dhaka. P. 138.

BBS (Bangladesh Bureau of Statistics). 2015. Estimates of Boro Rice (Husked), 2014-15. Pp. 1-6.

BINA ((Bangladesh Institutye of Nuclear Agriculture) 1987. Annual Report, 1986-87. Bangladesh Inst. Nucl. Agric. P.O. Box No. 4. Mymensingh. P. 165.

BINA (Bangladesh Institutye of Nuclear Agriculture) 1993. Annual Report, 1992-93. Bangladesh Inst. Nucl. Agric. P.O. Box No. 4. Mymensingh. Pp. 143-147.

Chowdhury, M. J. U., A. U. Sarker, M. A. R. Sarkar and M. A. Kashem. 1993. Effect of variety and number of seedlings hill ${ }^{-1}$ on the yield and its components of late transplant Aman rice. Bangladesh J. Agril. Sci. 20(2): 311-316.

FAO (Food and Agricultural Organization). 2005. FAO production year Book. Food and Agricultural organization, Rome. 59: 54.

Ghosh, B. C., M. D. Reddy and B. B. Reddy. 1988. Effect of seedling density on growth and yield of transplanted rice in an intermediate deep water situation. Thai J. Agril. Sci. 21(10): 1321.

Gomez K. A. and A. A. Gomez. 1984. Statistical Procedures for Agricultural Research. A Wiley Int. Sci. Pub. John Wiley and Sons, New York, Brisbane, Singapore. P.139

Islam, M. R., M. A. Salam, M. A. Harman and M. A. R. Sarkar 2002. Effect of hill density and number of seedlings hill-1 on the yield and yield components of fine rice $\mathrm{cv}$. Kalizira. Bangladesh J. Agril. Sci. 29(2): 325-328.

Kang, Y. K., H. T. Kim, N. K. Cho and Y. C. Kim. 2001. Effect of planting date and plant density on yield and quality of rice in Jeju. Korean J. Crop Sci. 46: 95-99.

Karmakar, B., M. A. R. Sarkar, M. R. Uddin and M. Biswas. 2002. Effect of row arrangements, number of seedlings hill ${ }^{-1}$ and nitrogen rates on yield and yield components of late transplant aman rice. Bangladesh. J. Agri1. Sci. 29(2): 275-281.

Miah, M. H. N., M. A. Karim, M. S. Rahman and M. S. Islam. 1990. Performance of Nizersail mutants under different row spacings. Bangladesh J. Train. Dev. 3(2): 31-34. 
Ninad et al.

Neelam, K. C. and C. Nisha. 2000. Effect of row spacing and nitrogen level on growth, yield and seed quality of scented rice under transplanted condition. Indian J. Agron. 45: 45: 304306.

Obulamma, U., R. Reddepa and R. Reddy. 2002. Effect of spacing and seedling number on growth and yield of hybrid rice. J. Res. Angrau. 30(1):76-78.

Sarker, G., M. Rahman, R. Hasan and S. C. Roy. 2002. System of rice intensification: Yield and economic potential in Boro rice at different locations of Bangladesh. LIFE-NOPEST project, CARE-Bangladesh. P. 1-5.

Shah, M. H., M. K. Khushu, B. A. Khanday, and A. S. Bali. 1991. Effect of spacing and seedlings per hill on transplanted rice under late sown condition. Indian J. Agron. 36(2): 274-275.

Shrirame, M. D., H. J. Rajgire and A. H. Rajgire. 2000. Effect of spacing and seedling number hill1on growth attributes and yield of rice hybrids under lowland condition. J. Soils Crops. 10(1):109-113. 